\title{
Landslide Hazard Maplies using Anbalagan Method and TOPSIS
}

\author{
Muh Joko Umbaran H. B. \\ Master of Information System \\ Universitas Diponegoro \\ Semarang, Indonesia
}

\author{
R. Rizal Isnanto \\ Computer Engineering \\ Universitas Diponegoro \\ Semarang, Indonesia
}

\author{
Oky Dwi Nurhayati \\ Computer Engineering \\ Universitas Diponegoro \\ Semarang, Indonesia
}

\begin{abstract}
Landslide disaster is the biggest disaster that can cause many casualties. to anticipate the lending land disaster that often occur in Indonesia made a public web bebasis application that can inform the area prone to landslides. The problem often faced is the identification of landslide-prone areas so that when landslide disaster occurs there are still many casualties. The purpose of this application is to determine the location of landslide-prone areas by using Anbalagan method and ranking based on TOPSIS as well as providing information to the public about areas prone to landslides. The method used in this research is anbalgan method with tehkni overlay and ranking method for TOPSIS. Making this Application using PHP programming language (Hypertext Prepocessor) and MySQL database. The results of this study is a public web that is useful to provide information to the public about avalanches that are prone to landslides..
\end{abstract}

\section{General Terms}

Mapping of landslide prone areas.

\section{Keywords}

TOPSIS Method, Anbalagan Method, Overlay Technique, Landslide, Web.

\section{INTRODUCTION}

Landslide disaster is the biggest disaster that many casualties. There are several factors that can trigger the occurrence of landslide disaster, such as heavy rain, sloped mountain slopes and fragile rocks and unstable soil conditions make these lands unable to hold water in the event of heavy rains. However, landslides can also be generated by volcanic or earthquake activity [1].

Through the events that have occurred in some time ago, it takes an understanding that can be used as input for local governments to give special attention to any areas that are at risk of landslides. Through a public website that can map any area prone to landslides so that decision-making and handling can be done as soon as possible. In order to minimize casualties caused by landslide disaster. The purpose of this study is to determine the areas that are at risk of landslides into the form of a public web map [2]. The method used in this study is Anbalagan method to determine the landslide and TOPSIS criteria to calculate the most vulnerable areas of landslides. The advantage of the Anbalagan method is that the landslide weights of the landslide criteria have been established and can be applied in various regions. TOPSIS method itself has calculations for ranking so it can be applied to the most vulnerable areas of landslides [3]. To determine the condition of the soil layer of a research area. The criteria contained in this method are six criteria. Among other lithology, soil structure, slope slope, relative relive, land cover, soil water condition. In this method also each weight has a default value of landslide vulnerability called Landslide Hazard Evaluation Factor (LHEF) [4]. In general, anbalag method discusses the comparison of some layer layers that can be used as criteria. The technique used to unify each of these criteria layers is called Overlay [5]. In the processing used a method that can streamline the results of each research site. Disadvantages of TOPSIS method itself is no determination of criteria weight. While the advantages of this method has a simple concept and easy to understand. Able to serve as an alternative performance measurement. Because these two methods complement each other TOPSIS method requires the weight value of each criteria contained in Anbalagan method [6]. The TOPSIS method assists in data processing and the determination of landslide prone areas.

\section{RESEARCH METHODOLOGY}

\subsection{Anbalagan}

Anbalagan method also has a standard value of landslide hazard factors that can be used as a reference weighting criteria in the TOPSIS method to calculate the ranking of the most vulnerable areas of landslides. The value of this weight is made in the form of Tables 1. of Landslide Hazard Evaluation Factor (LHEF).

Table 1 Landslide Hazard Evaluation Factor (LHEF)

\begin{tabular}{|l|l|}
\hline LHEF Factor & LHEF Value \\
\hline Lithology & 2 \\
\hline Soil Structure & 2 \\
\hline Slope & 2 \\
\hline Relative Relative & 1 \\
\hline Land Cover of & 1 \\
\hline $\begin{array}{l}\text { Condition } \\
\text { Ground Water }\end{array}$ & 10 \\
\hline Amount & \\
\hline
\end{tabular}

There are 6 criteria that will be used to determine the default value of the opponent landslide.

\subsection{TOPSIS Algorithm}

Steps used in TOPSIS method there are five stages [10]

Parameters

a. rij is the value of normalization

b. Xij is the value of an alternative

c. yij is a weighted normalized value

d. wi is the weight of each criterion

e. rij the normalization value of each alternative 
f. Vi value of preference for each alternative

g. Ai Distance between alternatives

Single objective optimization problem of TOPSIS

In general, the algorithm steps of TOPSIS are as follows .

1. Rating of each Alternative

$$
r_{i j}=\frac{x i j}{\sqrt{\sum_{i=1}^{m} x_{y}^{2}}}
$$

2. Normally Normalized Matrix

$$
y_{i j}=w_{i} r_{i j}
$$

3. Positive and Negative Ideal Solutions

$$
\begin{aligned}
& A+=(y 1+, y 2+, \ldots y n+) ; \\
& A^{-}=(y 1-, y 2-, \ldots y n-) ;
\end{aligned}
$$

4. Distance with Ideal Solution

$$
\begin{aligned}
& D_{i}^{+}=\sqrt{\sum_{j=1}^{n}\left(y_{i}^{+}-y_{i j}\right)^{2}} \\
& D_{i}^{-}=\sqrt{\sum_{j=1}^{n}\left(y_{i j}-y_{i}^{-}\right)^{2}}
\end{aligned}
$$

5. Preference Value For Any Alternative

$$
v_{i}=\frac{D_{i}^{-}}{\mathrm{D}_{i}^{-}+D_{i}^{+}} \text {. }
$$

\section{DESIGN OF RESEARCH}

\subsection{Material and Tools}

The method used in the data collection process there are two observation methods and method of Literature Review. The tools used in this research are hardware and software. The hardware needed in this research is a laptop with Processor Core i3 M390 with 4 GB RAM memory and software in this research is Adobe Dreamweaver CS6 as implementation of PHP programming for web development, MySQL database and ArcGIS Application for data processing and mapping of disaster prone locations.

\subsection{Research Procedure}

The procedure of this study is shown in Figure 1 as follows:

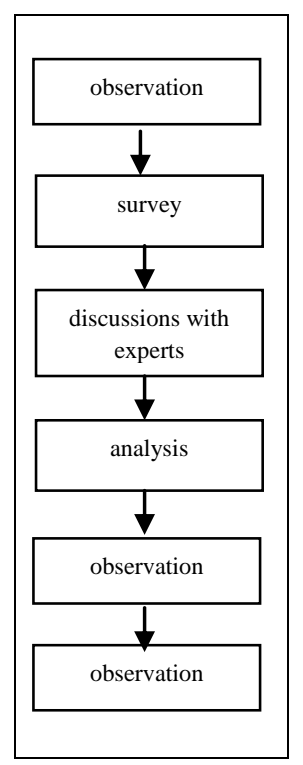

Fig. 1 Research Procedure

\subsection{Framework of Information System}

In this research using two methods in determining the location of landslide that is using Anbalagan Method and also TOPSIS. Anbalagan itself is used as a determinant of criteria in the topsis method and the TOPSIS method is used by the location determiner most vulnerable to landslides. In Figure 2. described the procedure to be run.There are six stages in this research procedure.

1. Input, data used in this research is field data and remote sensing map data.

2. Processing of sample data by conducting research directly in the field at the location of the research that has been determined.

3. Data Analysis is comparing the two data between field data and remote sensing map data by using Anbalagan method which will generate the weight value of criteria for each sample area.

4. Overlay Process is data that has been processed using Ambalagan method then overlayed using ArcGIS application to know the value of each alternative area.

5. Ranking Process, after the process of overlaying the data then the next ranking using TOPSIS method to determine the most vulnerable areas of landslides.Outputs, the results of the research undertaken determine the most vulnerable Locations of Locations so that action can be taken directly in the area.

\begin{tabular}{|l|l|l|}
\hline Input & Process & Output \\
\hline Map Data & \multicolumn{1}{|c|}{\begin{tabular}{|c} 
The result is a \\
web information \\
area prone to \\
landslides
\end{tabular}} \\
\hline Overlay Process & \\
\hline Process Ranking \\
\hline
\end{tabular}

Fig. 2 Framework Information System

\section{RESULT}

The value of the analysis results obtained from each weight of the lithology criteria, soil structure, slope slope, relief relief, land cover, ground water conditions. Each village classifies each weight with anbalagan method. This weight will be used for calculation using TOPSIS method as the most vulnerable area ranks of landslide.

\subsection{Overlay Results}

Based on the landslide vulnerability map (Figure 3), the study area has five classes of landslide zone ranging from very low vulnerability zones to very high vulnerability zones. The relatively low dominant vulnerability zone is located in the southern area of the study area. While the relatively high vulnerability zone is located in the northern area of the research area. 


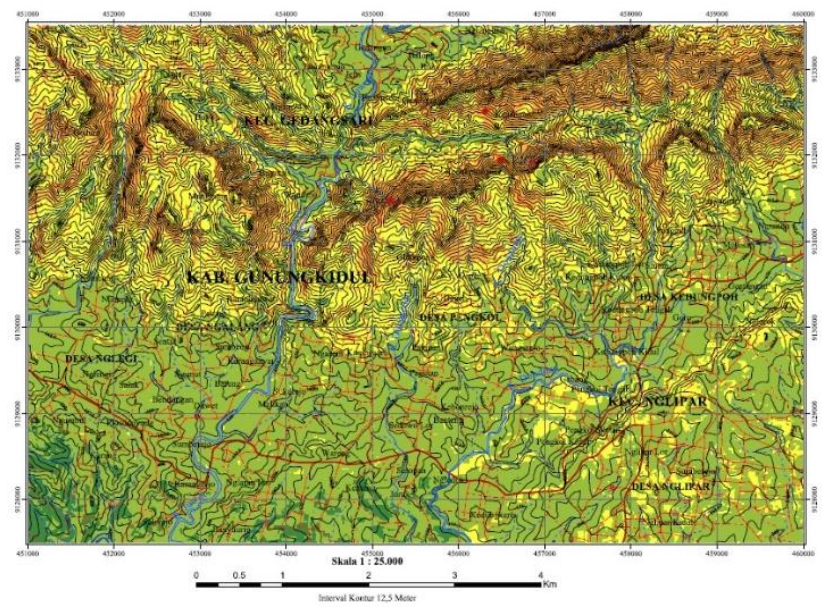

Fig. 3 Overlay

Very low vulnerability zone is very striking in the area of Wonosari Formation which is composed by dominant limestone which is physically limestone is a resistant rock. While the highly susceptible zone in the landslide vulnerability map (Figure 8.) has a spot-spot distribution. Nevertheless, in the high landslide vulnerability map still shows a large area in the research area.

Table 3. Analysis results

\begin{tabular}{|l|l|l|l|l|l|l|}
\hline Area & \multicolumn{5}{|l|}{ Value } \\
\hline Ngalang & 4 & 4 & 5 & 3 & 3 & 3 \\
\hline Ngelegi & 3 & 5 & 2 & 3 & 3 & 2 \\
\hline Kacangan & 5 & 4 & 4 & 3 & 3 & 5 \\
& & & & & & \\
\hline
\end{tabular}

Table 3. explains that each region is explained about each of the criteria weights that include: groundwater conditions, land cover, slope, soil structure, lithology. This data is taken from the Overlay process of a map. Alternative which is used in this case there are 3 area at Gunung Kidul, Yogyakarta with skale $9 \mathrm{KM}$ x $6 \mathrm{KM}$ :

1. A01 Karang Duwet Region - Ngalang Village. At this point the morphology found a steep slope morphology with rock formationsof andesite bereksi constituent tracking. Tilt of the slope is relatively large and the condition of the ground water surface seeps.

2. A02 Kembang Region - Ngelegi Village. The soil material is a mixture of soil and rotted fregmen breksi andesite. Other indications of the existence of the root of the tree that hangs the rock indicating that prop up that tree has been lost.

3. A03 Kacangan Region - Hargomulyo village. Landslide material is a mixture of soil and rock in the form of Tuff that is breezy rock formations (Obsolescent) is characterized by the loss of grass vegetation.

\subsection{Criteria values}

The value of each criterion is determined based on the result of the overlay of the research area and based on the LHEF table in which this table becomes the reference point of the determination of each creteria weight. the following table 4 describes the value of each criterion.
Table 4. Weighting value

\begin{tabular}{|l|l|}
\hline \multicolumn{2}{|l|}{ Weighting value (w) } \\
\hline C1 & 5 \\
\hline C2 & 3 \\
\hline C3 & 4 \\
\hline C4 & 4 \\
\hline C5 & 2 \\
\hline C6 & 4 \\
\hline
\end{tabular}

The attributes of each of these criteria are taken based on the value of landslide susceptibility factor in the LHEF table. Benefit if the value of the area below the value of landslide vulnerability. otherwise it is said cost if the factor value of a criterion area exceeds the standard threshold of LHEF determination. Table 5. describes the criterion attributes at the study site.

Tabel 5. Atribut Kriteria

\begin{tabular}{|l|l|l|}
\hline Code & Criteria Name & attribute \\
\hline C01 & Soil Water Conditions & Benefit \\
\hline C02 & Land Cover & Benefit \\
\hline C03 & Relative Relief & Cost \\
\hline C04 & The tilt of the slope & Cost \\
\hline C05 & Soil Structure & Cost \\
\hline C06 & Litologi & Benefit \\
\hline
\end{tabular}

\subsection{Normalization}

Each criterion is calculated using the normalization formula of (x1), (x2), (x3), (x4), (x5), (x6) and the result (r) is used to calculate the normalization weight. The results are listed in Table 6.

Tabel 6. Normalization Results

\begin{tabular}{|l|l|l|l|l|l|}
\hline C01 & C02 & C03 & C04 & C05 & C06 \\
\hline 0.49237 & 0.44173 & 0.64018 & 0.41603 & 0.37796 & 0.37796 \\
\hline 0.36927 & 0.55216 & 0.25607 & 0.41603 & 0.37796 & 0.25198 \\
\hline 0.61546 & 0.44173 & 0.51215 & 0.41603 & 0.37796 & 0.62994 \\
\hline 0.49237 & 0.55216 & 0.51215 & 0.69338 & 0.75593 & 0.62994 \\
\hline
\end{tabular}

\subsection{Weighted Normalization}

After calculating the normalized value, the next step is to calculate the weighted normalization value by multiplying the value in each alternative of the normalized matrix by the weights given by the decision maker. The results are listed in Table 7. 
Tabel 7. Weighted Normalization Results

\begin{tabular}{|l|l|l|l|l|l|}
\hline $\mathbf{C 0 1}$ & $\mathbf{C 0 2}$ & $\mathbf{C 0 3}$ & $\mathbf{C 0 4}$ & $\mathbf{C 0 5}$ & $\mathbf{C 0 6}$ \\
\hline 2.46183 & 1.32518 & 2.56074 & 1.6641 & 0.75593 & 1.51186 \\
\hline 1.84637 & 1.65647 & 1.0243 & 1.6641 & 0.75593 & 1.00791 \\
\hline 3.07729 & 1.32518 & 2.04859 & 1.6641 & 0.75593 & 2.51976 \\
\hline 2.46183 & 1.65647 & 2.04859 & 2.7735 & 1.51186 & 2.51976 \\
\hline
\end{tabular}

\subsection{Ideal Solution Matrix}

The positive Ideal Solution $\left(\mathrm{A}^{+}\right)$is obtained by finding the maximum value of the weighted normalization value $\left(\mathrm{y}^{\mathrm{ij}}\right)$ if the attribute is a gain attribute and finding the minimal value of the weighted normalization value $\left(\mathrm{y}^{\mathrm{ij}}\right)$ if the attribute is a cost attribute. The negative Ideal Solution $\left(\mathrm{A}^{-}\right)$is obtained by finding the minimal value of the weighted normalization value $\left(y^{i j}\right)$ if the attribute is the profit attribute and the maximum value of the weighted normalization value $\left(\mathrm{y}^{\mathrm{ij}}\right)$ if the attribute is the cost attribute. The results are listed in Table 8 .

Tabel 8. Ideal Solution Matrix Result

\begin{tabular}{|l|l|l|l|l|l|l|}
\hline $\begin{array}{l}\text { Altern } \\
\text { atif }\end{array}$ & $\mathbf{C 0 1}$ & $\mathbf{C 0 2}$ & $\mathbf{C 0 3}$ & $\mathbf{C 0 4}$ & $\mathbf{C 0 5}$ & $\mathbf{C 0 6}$ \\
\hline Positif & $\begin{array}{l}3.077 \\
29\end{array}$ & $\begin{array}{l}1.656 \\
47\end{array}$ & $\begin{array}{l}1.024 \\
3\end{array}$ & $\begin{array}{l}1.66 \\
41\end{array}$ & $\begin{array}{l}0.755 \\
93\end{array}$ & $\begin{array}{l}2.519 \\
76\end{array}$ \\
\hline Negatif & 1.846 & $\begin{array}{l}1.325 \\
18\end{array}$ & $\begin{array}{l}2.560 \\
74\end{array}$ & $\begin{array}{l}2.77 \\
35\end{array}$ & $\begin{array}{l}1.511 \\
86\end{array}$ & $\begin{array}{l}1.007 \\
91\end{array}$ \\
& 37 & 18 & & \multicolumn{3}{|c|}{} \\
\hline
\end{tabular}

\subsection{Results Distance Solutions and \\ Preference Values}

$\mathrm{V}_{\mathrm{i}}$ (value of preference for each alternative) is obtained from the value of the ideal ideal solution distance $\left(\mathrm{D}^{\mathrm{i}-}\right)$ divided by the number of negative ideal solution distance value ( $\mathrm{Di}^{-}$) plus the value of the ideal ideal solution distance $\left(D^{i+}\right)$ With $\mathrm{i}=$ 1,2 ..., $\mathrm{m}$. A larger $\mathrm{V}$ value indicates that an alternative $\mathrm{Ai}$ is more appropriately selected. All criteria on the topsis will be weighted by priority. The results are listed in Table 9 .

Tabel 9. Results Distance Solutions and Preference Values

\begin{tabular}{|l|l|l|l|}
\hline Alternatif & Positif & Negatif & Preferensi \\
\hline A03 & 1.07654 & 2.42185 & 0.69228 \\
\hline A02 & 1.94958 & 2.06703 & 0.51462 \\
\hline A04 & 1.79727 & 1.74257 & 0.49227 \\
\hline A01 & 1.96598 & 1.56043 & 0.4425 \\
\hline
\end{tabular}

\subsection{Final Results}

From the processing done got an area that has an indication of landslide prone and be ranked based on the vulnerability.

Tabel 10. Result Rank Analysis

\begin{tabular}{|l|l|l|}
\hline Alternatif & Total & Rank \\
\hline A03 & 0.692 & 1 \\
\hline A02 & 0.515 & 2 \\
\hline A04 & 0.492 & 3 \\
\hline A01 & 0.442 & 4 \\
\hline
\end{tabular}

\section{CONCLUSION}

From the research that has been done, the result of the ranking of the most vulnerable areas of landslide is 4 dertah and the area has high vulnerability of Hargomulyo village with alternative A03 with total weight $(0,692)$. Using TOPSIS method to rank the most vulnerable areas of landslides will facilitate geological in conducting real time research as it can be done through the website.

\section{REFERENCES}

[1] Aronica., Biondi., Brigandì., Cascone., Lanza, R., (2012), Assessment and mapping of debris-flow risk in a small catchment in eastern Sicily through integrated numerical simulations and GIS. Journal of Physics and Chemistry of the Earth, 49, 52-63.

[2] Bozorgi, A., Asvadi, S., (2015), A prioritization model for locating relief logistic centers using analytic hierarchy process with interval comparison matrix. Knowledge-Based Systems, 86, 173-181.

[3] J. Chu and Y. Su, "The Application of TOPSIS Method in Selecting Fixed Seismic Shelter for Evacuation in Cities," Syst. Eng. Procedia, vol. 3, no. 2011, pp. 391397, 2012.

[4] Coutinho, R., Simao., Antunes., (2011), A GIS-based multicriteria spatial decision support system for planning urban infrastructures. Journal of Decision Support Systems, 51, 720-726.

[5] Perpina., dan Pérez, N., (2013), Multicriteria assessment in GIS environments for siting biomass plants. Land Use Policy, Journal of Renewable and Sustainable Energy Reviews, 31, 326-335.

[6] Ameri, H. R. Pourghasemi, and A. Cerda, "Erodibility prioritization of sub-watersheds using morphometric parameters analysis and its mapping: A comparison among TOPSIS, VIKOR, SAW, and CF multi-criteria decision making models," Sci. Total Environ., vol. 613614, pp. 1385-1400, 2018.

[7] Hamza., dan Raghuvanshi., (2017), GIS based landslide hazard evaluation and zonation a case from Jeldu District, Central Ethiopia. Journal of King Saud University - Science, vol. 29, 151-165.

[8] Jianyu, C., Youpo, S., (2012),"The application of TOPSIS method in selecting fixed seismic shelter for evacuation in cities",Science Direct.

[9] Rossi, P., Amadio, R., dan Soliani., (2008), Coupling indicators of ecological value and ecological sensitivity with indicators of demographic pressure in the demarcation of new areas to be protected: The case of the Oltrep Pavese and the Ligurian-Emilian Apennine area (Italy). Journal of Landscape and Urban Planning, 85, 12-26.

[10] Turkey, C., Eren, O., Mehmet, E., Mehmet, K., (2016)., "GIS-based Fuzzy MCDA Approach for Siting Refugee Camp: A Case Study for Southeastern" International Journal of Disaster Risk Reduction.

[11] Zyoud, S.H., Fuchs, H.D., (2017), A bibliometric-based survey on AHP and TOPSIS techniques. Expert Systems with Applications, Journal of Renewable and Sustainable Energy Reviews, 78, 158-181.

[12] W. Chen et al., "GIS-based landslide susceptibility evaluation using a novel hybrid integration approach of bivariate statistical based random forest method," Catena, vol. 164, no. April 2017, pp. 135-149, 2018.

[13] T. K. Raghuvanshi, L. Negassa, and P. M. Kala, "GIS based Grid overlay method versus modeling approach A comparative study for landslide hazard zonation (LHZ) in Meta Robi District of West Showa Zone in 
Ethiopia,” Egypt. J. Remote Sens. Sp. Sci., vol. 18, no. 2, pp. 235-250, 2015.

[14] S. Chauhan, M. Sharma, M. K. Arora, and N. K. Gupta, "Landslide susceptibility zonation through ratings derived from artificial neural network," Int. J. Appl. Earth Obs. Geoinf., vol. 12, no. 5, pp. 340-350, 2010.

[15] M. Torkashvand, A. Irani, and J. Sorur, "The preparation of landslide map by Landslide Numerical Risk Factor (LNRF) model and Geographic Information System (GIS)," Egypt. J. Remote Sens. Sp. Sci., vol. 17, no. 2, pp. 159-170, 2014.

[16] P. Reichenbach, M. Rossi, B. D. Malamud, M. Mihir, and F. Guzzetti, "A review of statistically-based landslide susceptibility models," Earth-Science Rev., vol. 180, no. March, pp. 60-91, 2018.

[17] T. Hamza and T. K. Raghuvanshi, "GIS based landslide hazard evaluation and zonation - A case from Jeldu District, Central Ethiopia," J. King Saud Univ. - Sci., vol. 29, no. 2, pp. 151-165, 2017.

[18] W. Chen et al., "GIS-based landslide susceptibility evaluation using a novel hybrid integration approach of bivariate statistical based random forest method," Catena, vol. 164, no. April 2017, pp. 135-149, 2018.

[19] S. Chauhan, M. Sharma, M. K. Arora, and N. K. Gupta, "Landslide susceptibility zonation through ratings derived from artificial neural network," Int. J. Appl. Earth Obs. Geoinf., vol. 12, no. 5, pp. 340-350, 2010.

[20] M. Torkashvand, A. Irani, and J. Sorur, "The preparation of landslide map by Landslide Numerical Risk Factor (LNRF) model and Geographic Information System (GIS),” Egypt. J. Remote Sens. Sp. Sci., vol. 17, no. 2, pp. 159-170, 2014S. Kaboodvandpour and L. K. P. Leung, "Modelling density thresholds for managing mouse damage to maturing wheat," Crop Prot., vol. 42, pp. 134-140, 2012.

[21] Y. G. Lou, G. R. Zhang, W. Q. Zhang, Y. Hu, and J. Zhang, "Reprint of: Biological control of rice insect pests in China," Biol. Control, vol. 68, no. 1, pp. 103-116, 2014.

[22] Walters and Q. Cai, "Investigating the Use of HoltWinters Time Series Model for Forecasting Population at the State and Sub-State Levels," J. Demogr. Work. Sect., vol. 2, pp. 7-8, 2008.

[23] Ganatra, Y. P. Kosta, G. Panchal, and C. Gajjar, "Initial Classification Through Back Propagation In a Neural
Network Following Optimization Through GA to Evaluate the Fitness of an Algorithm," Int. J. Comput. Sci. Inf. Technol., vol. 3, no. 1, pp. 98-116, 2011.

[24] J. Tarigan, Nadia, R. Diedan, and Y. Suryana, "Plate Recognition Using Backpropagation Neural Network and Genetic Algorithm," Procedia Comput. Sci., vol. 116, pp. 365-372, 2017.

[25] P. Kalekar, "Time series forecasting using Holt-Winters exponential smoothing," Kanwal Rekhi Sch. Inf. Technol., no. 04329008, pp. 1-13, 2004.

[26] S. . Kosbatwar and S. . Pathan, "Pattern Association for Character Recognition by Back Propagation Algorithm Using Neural Network Approach,” Int. Comput. Sci. Eng. Surv., vol. 3, no. 1, pp. 127-34, 2012.

[27] R. Tripathi et al., "Forecasting Rice Productivity and Production of Odisha , India , Using Autoregressive Integrated Moving Average Models," Adv. Agric., vol. 1 , pp. 1-9, 2014

[28] Chatfield and M. Yar, "Holt-Winters Forecasting: Some Practical Issues," Source J. R. Stat. Soc. Ser. D (The Stat. J. R. Stat. Soc. Ser. D Stat., vol. 37, no. 2, pp. 129-140, 1988.

[29] L. Ferbar Tratar and E. Strmčnik, "The comparison of Holt-Winters method and Multiple regression method: A case study," Energy, vol. 109, pp. 266-276, 2016.

[30] N. A. Elmunim, M. Abdullah, A. M. Hasbi, and S. A. Bahari, "Comparison of GPS TEC variations with HoltWinter method and IRI-2012 over Langkawi, Malaysia," Adv. Sp. Res., vol. 60, no. 2, pp. 276-285, 2017.

[31] G. Tirkeş, C. Güray, and N. Çelebi, "Demand forecasting: a comparison between the Holt-Winters, trend analysis and decomposition models," Teh. Vjesn. Tech. Gaz., vol. 24, no. Supplement 2, pp. 503-509, 2017.

[32] U. Khair, H. Fahmi, S. Al Hakim, and R. Rahim, "Forecasting Error Calculation with Mean Absolute Deviation and Mean Absolute Percentage Error," J. Phys. Conf. Ser., vol. 930, no. 1, pp. 1-6, 2017.

[33] W. N. Networks, W. Now, H. Are, and N. Networks, Fundamental of Neural Network:: Architecture, Algorithm, and Application. New Jarsey: Prentice-Hall, 1994.

[34] T. Baldigara, "Forecasting Tourism Demand in Croatia: A Comparison of Different Extrapolative Methods," J. Bus. Adm. Res., vol. 2, no. 1, pp. 84-92, 2013. 